\title{
Technical and economic feasibility of irrigated wheat as a function of nitrogen doses, sources, and inoculation with Azospirillum brasilense
}

\author{
Viabilidade técnica e econômica do trigo irrigado em \\ função de doses e fontes de nitrogênio e à inoculação \\ com Azospirillum brasilense
}

\author{
Fernando Shintate Galindo ${ }^{1 *}$; Marcelo Carvalho Minhoto Teixeira Filho ${ }^{2}$; \\ Maria Aparecida Anselmo Tarsitano²; Salatiér Buzetti²; José Mateus Kondo \\ Santini³; Mariana Gaioto Ziolkowski Ludkiewicz'; Cleiton José Alves ${ }^{4}$
}

\begin{abstract}
Azospirillum brasilense is a bacterium known for its biological nitrogen fixation (BNF) in wheat crops. However, there is a lack of comprehensive research defining how much mineral $\mathrm{N}$ should be applied to maximize the efficiency of BNF and attain high, economically sustainable yields. Moreover, it would be interesting to investigate whether adding urea with $\mathrm{N}$ - (n-butyl) thiophosphoric triamide (NBPT) urease inhibitor might increase BNF in grasses. The objective was to study the effect of inoculation with $A$. brasilense, associated with varying doses and sources of $\mathrm{N}$, and economically evaluating the yield of irrigated wheat. The experiment was conducted in Selvíria - MS in crop years 2014 and 2015 in Oxisol soil type that was not-tilled. The experimental design was a randomized block with four replications, in a $2 \times 5 \times 2$ factorial scheme, where $2 \mathrm{~N}$ sources (urea and Super $\mathrm{N}$ - urea with urease inhibitor enzyme), 5 nitrogen fertilization doses in top-dressing $\left(0,50,100,150\right.$, and $\left.200 \mathrm{~kg} \mathrm{ha}^{-1}\right)$, were applied to wheat crops with or without the inoculation of $A$. brasilense. Our results showed that the supply of $\mathrm{N}$ through Super $\mathrm{N}$ was not economically superior to the use of conventional urea; therefore, we recommend the use of urea because of the ease of acquisition. The application of $140 \mathrm{~kg} \mathrm{ha}^{-1}$ of $\mathrm{N}$ combined with inoculation with $A$. brasilense showed higher grain yield. However, the $50 \mathrm{~kg} \mathrm{ha}^{-1}$ dose of urea in the absence of inoculation provided greater economic viability in wheat cultivation, but was not sufficient to ensure high profitability with grain productivity.
\end{abstract}

Key words: Triticum aestivum. Nitrogen fertilization. Total operational cost. No tillage system.

\section{Resumo}

O Azospirillum brasilense se destaca na fixação biológica de nitrogênio (FBN) em cultivo de trigo. Contudo, faltam maiores pesquisas para definição do quanto se pode aplicar de $\mathrm{N}$ mineral quanto à eficiência da FBN, para alcançar altas produtividades economicamente sustentáveis. Além disso, seria interessante analisar se a ureia com inibidor da enzima urease NBPT pode ser menos prejudicial,

\footnotetext{
${ }^{1}$ Discentes de Doutorado, Programa de Pós-Graduação em Agronomia, Universidade Estadual Paulista, UNESP, Campus de Ilha Solteira, Ilha Solteira, SP, Brasil. E-mail: fs.galindo@yahoo.com.br; mariana.gaioto@gmail.com

2 Profs. Drs., UNESP, Ilha Solteira, SP, Brasil.E-mail: mcmtf@yahoo.com.br; maat@agr.feis.unesp.br; sbuzetti@agr.feis.unesp.br

3 Prof. M.e, Instituto de Ensino Superior de Rio Verde, IESRIVER, Rio Verde, GO, Brasil. E-mail: santini@faculdadeobjetivo. com.br

${ }^{4}$ Discente de Doutorado, Programa de Pós-Graduação em Agricultura, UNESP, Botucatu, SP, Brasil. E-mail: cleiton.agr.feis@ gmail.com

* Author for correspondence
} 
beneficiando a FBN em gramíneas. Sendo assim, objetivou-se estudar o efeito da inoculação com Azospirillum brasilense, associado às doses e fontes de N, avaliando economicamente a produtividade de grãos de trigo irrigado. O experimento foi desenvolvido em Selvíria - MS, nos agrícolas de 2014 e 2015, em sistema plantio direto, em Latossolo Vermelho distroférrico. O delineamento experimental foi em blocos aoacaso, com quatro repetições, dispostos em um esquema fatorial $2 \times 5 \times 2$, sendo: 2 fontes de N (ureia e Super N - ureia com inibidor da enzima urease; 5 doses de N em cobertura $(0,50,100,150$ e $200 \mathrm{~kg} \mathrm{ha}^{-1}$ ); com e sem inoculação de sementes com A. brasilense. O fornecimento de $\mathrm{N}$ por meio do Super N não foi economicamente superior ao uso de ureia convencional, portanto recomenda-se utilizar a ureia em função da facilidade de aquisição. A aplicação de $140 \mathrm{~kg} \mathrm{ha}^{-1} \mathrm{de} \mathrm{N}$ aliada à inoculação com $A$. brasilense proporcionou maior produtividade de grãos, entretanto a dose de $50 \mathrm{~kg} \mathrm{ha}^{-1}$, na ausência de inoculação e com a fonte ureia, proporcionou maior viabilidade econômica no cultivo de trigo, todavia não é suficiente para garantir elevada lucratividade com a produção de grãos.

Palavras-chave: Triticum aestivum. Adubação nitrogenada. Custo operacional total. Sistema plantio direto.

\section{Introduction}

In the 2017 harvest, the Brazilian area planted with wheat was around 2 million hectares, with a production of 5.2 million tons and a productivity of $2.7 \mathrm{t} \mathrm{ha}^{-1}$. The consumption of wheat in Brazil was approximately 11.4 million tons of grains of which, about $60 \%$ had to be imported, making Brazil dependent on countries like Argentina, Canada, and the United States of America, paying prices higher than the indigenous product. These are attributed mainly to the lack of public policies for cultivation of wheat and adverse climatic conditions in recent years. Although the southern region is responsible for approximately $90 \%$ of the national production, the cereal has been introduced gradually in the Cerrado region, both under irrigation or dry land (CONAB, 2017).

The Cerrado region has great potential for the expansion of triticulture as it offers favorable conditions of climate and soil, strategic market position and industrialization capacity, as well as being able to be harvested in the off-season of the southern states of Brazil and Argentina (ALBRECHT et al., 2006). However, many soils cultivated with wheat in the Cerrado region and in the state of São Paulo are acidic and of low fertility, which limits grain yield (GALINDO et al., 2017). In order to obtain high grain yields of this cereal it is necessary to apply high nitrogen $(\mathrm{N})$ doses, because the soils, in general, are unable to supply the required levels throughout the lifecycle of these plants. Therefore, nitrogen fertilization management is carried out with the aim of guaranteeing high productivity and, because of the dynamics of $\mathrm{N}$ in the soil, large amounts of this nutrient are added, which increases the farmer's production cost (TEIXEIRA FILHO et al., 2014).

In studies on nitrogen fertilization of maize cover, conducted by Lara Cabezas et al. (2000), it is estimated that there may be a reduction in maize grain yield due to the volatilization of $\mathrm{N}_{-} \mathrm{NH}_{3}$ in the ratio of $10 \mathrm{~kg} \mathrm{ha}^{-1}$ of grains to every $1 \%$ of volatilized $\mathrm{N}$. In this context, one possibility of increasing the efficiency of the nitrogen fertilization is the use of the N- (n-butyl) thiophosphoric triamide (NBPT) inhibitor, which can delay the hydrolysis of urea and significantly reduces $\mathrm{NH}_{3}$ losses, depending on the climatic conditions.

Among the products tested as a urease inhibitor, NBPT is the one that has been obtaining the best results (PRANDO et al., 2013). Some results obtained in studies carried out in temperate countries also prove this (ABALOS et al., 2014; CUI et al., 2010; LINQUIST et al., 2013). Most studies carried out in Brazil have shown that urea with urease inhibitor and conventional urea have the same efficiency in the nutrition and yield of wheat grains. In other words, the inhibitory action of urease has not been effective in reducing $\mathrm{NH}_{3}$ volatilization losses, since the action of NBPT 
depends on meteorological conditions (temperature and precipitation) and soil physical and chemical characteristics (CANTARELLA et al., 2008).

One of the alternatives to reduce the cost of production because of the use of high cost of fertilizers, would be incorporating the use of inoculants containing bacteria that promote growth and increase plant productivity. In Brazil, biological nitrogen fixation (BNF) by Azospirillum in associations with grasses has been well researched, but until recently there were no commercial inoculants with these bacteria in the country (HUNGRIA, 2011).

Several studies have confirmed that Azospirillum produces phytohormones that stimulate root growth of several plant species (BARASSI et al., 2008; BASHAN et al., 2006; TIEN et al., 1979). However, although most of the research involving seed inoculation using Azospirillum ssp. have reported some benefits relating to the phytohormonal effect, nitrogen fixation potential, and drought tolerance, the increase in grain yields of wheat was not always observed (FERREIRA et al., 2014; GALINDO et al., 2015; NUNES et al., 2015). This indicates that additional studies of this nature are important. In addition, there is a lack of research done to define the amount of mineral $\mathrm{N}$ required to be applied to succeed in BNF and reach high grain yield.

In view of the above, it is necessary to look for viable alternatives to increase the efficiency of nitrogen fertilization, making possible a reduction in the amount applied to the production system, without causing a reduction in the production and the quality of agricultural products. However, there are few studies that report the economic benefits of inoculation with Azospirillum brasilense when associated with various sources of $\mathrm{N}$ and for different $\mathrm{N}$ doses applied to the plant. To be viable to the farmer, it is not enough that technological innovations raise productivity. Studies should jointly report the economic viability (KANEKO et al., 2015).
Thus, the objective of this study was to verify the effect of the inoculation with Azospirillum brasilense, in association with various doses and sources of $\mathrm{N}$, and economically evaluate the yield of wheat grains cultivated in the Cerrado region.

\section{Material and Methods}

The study was conducted in the experimental area of the Faculty of Engineering - UNESP, located in Selvíria - MS, at an altitude of $335 \mathrm{~m}$. The soil of the experimental area was classified as a dystrophic Red Latosol, with clay texture (EMBRAPA, 2013), cultivated with annual crops for more than 27 years, the last 10 years under no-tillage system. In 2014 and 2015, the crop prior to sowing wheat was maize. Figure 1 shows the meteorological conditions (temperature, precipitation, and relative humidity) during the experiment.

The experimental design was a randomized complete block design with four replicates, arranged in a $2 \times 5 \times 2$ factorial scheme, which included two sources of $\mathrm{N}$ (conventional urea, $45 \% \mathrm{~N}$ and Super $\mathrm{N}$ - urea with inhibitor of the enzyme urease NBPT $(45 \% \mathrm{~N})$; five $\mathrm{N}$ doses $(0,50,100,150$, and 200 $\mathrm{kg} \mathrm{ha}^{-1}$ ) applied by broadcast cover; and treatments with and without inoculation of the seeds with $A$. brasilense. The study plots were $6 \mathrm{~m}$ in length with 12 rows of wheat with spacing of $0.17 \mathrm{~m}$, and plot area of 8 central lines, excluding $0.5 \mathrm{~m}$ from the extremities.

The herbicides glyphosate (1800 $\mathrm{g}$ ai ha $\left.{ }^{-1}\right)$ and 2,4-D (670 $\left.\mathrm{g}_{\text {ai }} \mathrm{ha}^{-1}\right)$ were applied to the area two weeks before planting wheat, both in 2014, and 2015. The chemical attributes of the soil in the $0-20 \mathrm{~cm}$ layer were determined according to the methodology proposed by Raij et al. (2001), and showed the following results: $13 \mathrm{mg} \mathrm{dm}^{-3}$ of $\mathrm{P}$ (resin); $6 \mathrm{mg} \mathrm{dm}^{-3}$ of S-SO $; 23 \mathrm{~g} \mathrm{dm}^{-3}$ O.M.(organic matter); $4.8 \mathrm{pH}\left(\mathrm{CaCl}_{2}\right) ; \mathrm{K}, \mathrm{Ca}, \mathrm{Mg}, \mathrm{H}+\mathrm{Al}=2.6$, 13.0, 8.0, and $42.0 \mathrm{mmol}_{\mathrm{c}} \mathrm{dm}^{-3}$, respectively; $\mathrm{Cu}$, $\mathrm{Fe}, \mathrm{Mn}, \mathrm{Zn}(\mathrm{DTPA})=5.9,30.0,93.9$, and $1.0 \mathrm{mg}$ $\mathrm{dm}^{-3}$, respectively; $0.24 \mathrm{mg} \mathrm{dm}^{-3} \mathrm{~B}$ (hot water); and $36 \%$ base saturation. 
Based on the soil analysis and with the aim of increasing the base saturation to $70 \%, 2.5 \mathrm{t} \mathrm{ha}^{-1}$ of dolomitic limestone (PRNT $=88 \%$ ) was applied, as recommended by Cantarella et al. (1997), 65 days before the sowing of maize crop, the predecessor to the wheat in 2014. Fertilization at the time of planting included $350 \mathrm{~kg} \mathrm{ha}^{-1}$ of the formula $08-28$ 16 , which was based on the soil analysis and the crop requirement, in both crops.

Figure 1. Precipitation, relative humidity, and maximum, average, and minimum temperatures obtained during the wheat experiment in 2014 (A) and 2015 (B) at the meteorological station located at the Teaching, Research and Extension Farm FE/UNESP. The period from May to September 2014 (A) and 2015 (B) are shown.

A.

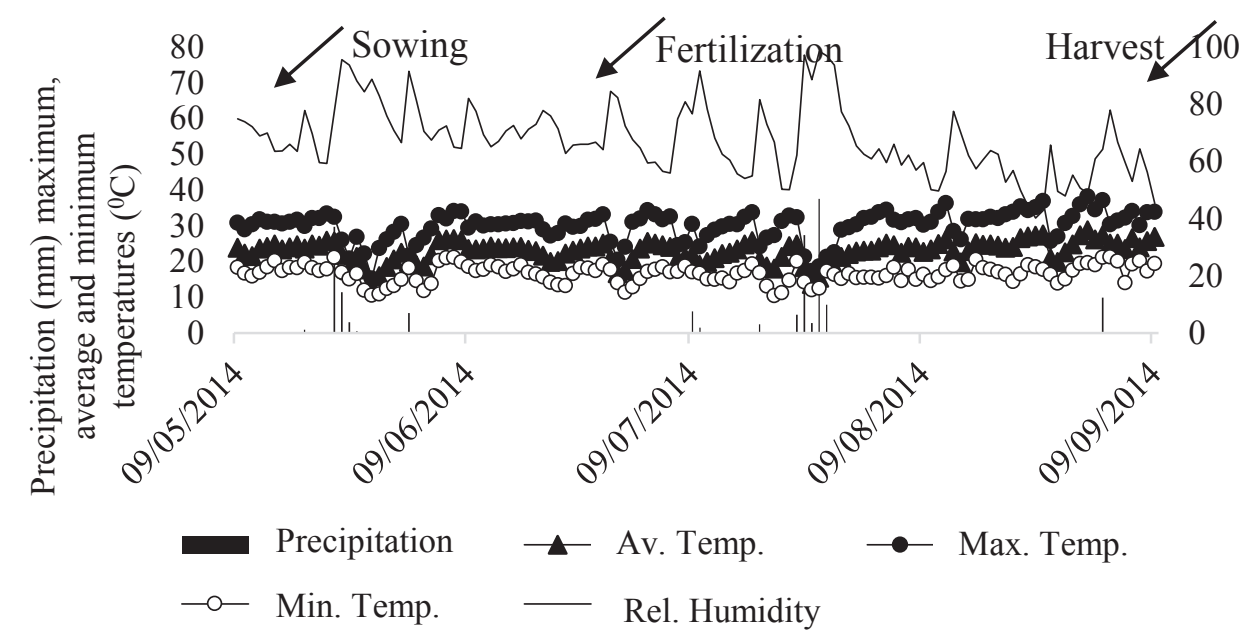

B.

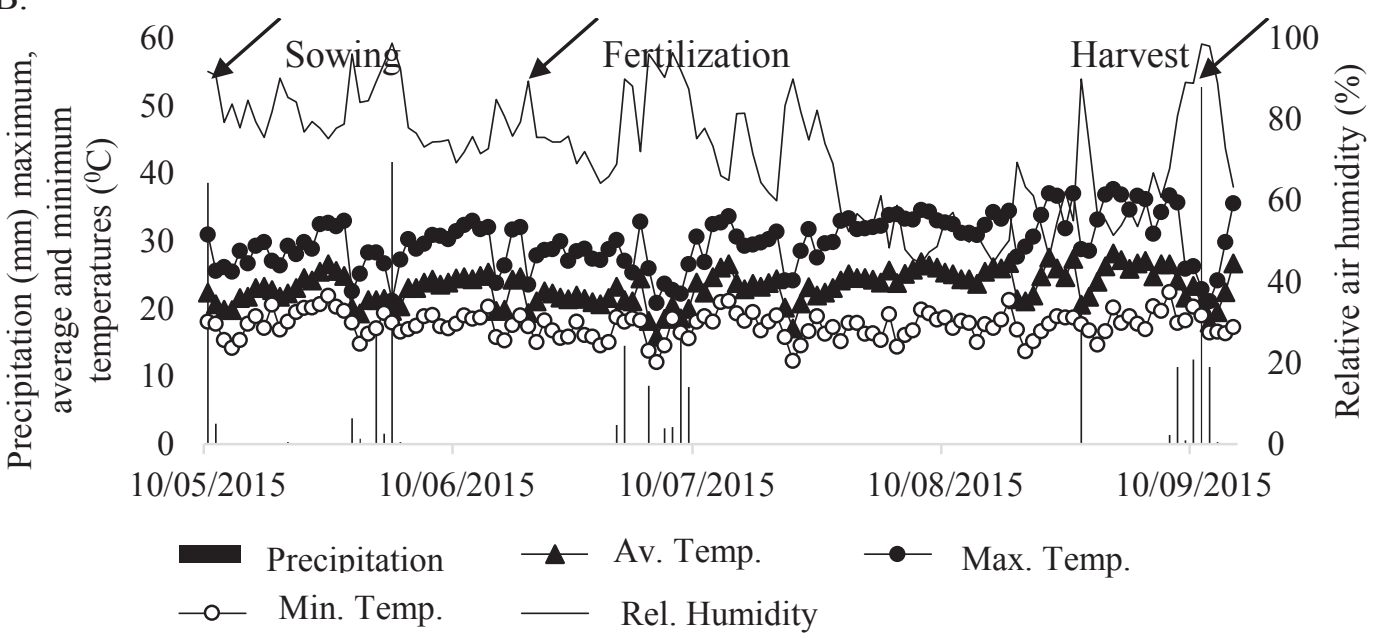

The inoculation of wheat seeds with the bacterium Azospirillum brasilense strains AbV5 and AbV6 (guarantee of $2 \times 10^{8} \mathrm{CFU} \mathrm{mL}^{-1}$ ) was carried out at 300 $\mathrm{ml}$ dose of inoculants (net) per hectare of wheat seeds sown (300 mL per $150 \mathrm{~kg}$ of seeds), one hour before sowing the crops and after the treatment of seeds with insecticide. In the treatment of seeds, Carbendazim + Thiran fungicides $(45+105 \mathrm{~g}$ ai per $100 \mathrm{~kg}$ seed $)$ and the insecticide Imidacloprid + Thiodicarb $(45+135$ g.ai per $100 \mathrm{~kg}$ seed) were used.

The experiments were conducted in a no-tillage system. The area was irrigated by a central pivot 
type sprinkler system with an average water depth of $14 \mathrm{~mm}$ and irrigation time of approximately 72 hours in both crops, when necessary. Seeding was performed mechanically using cultivar CD 116 in May 2014 (harvest 2014) and 2015 (harvest 2015) with 80 seeds per linear meter. Seedling emergence occurred on the sixth and fifth day after sowing (05/22/2014 and 05/20/2015).

Weed management was carried out with the application of the herbicide MetsulfuronMethyl (3.0 $\mathrm{g}_{\text {ai }} \mathrm{ha}^{-1}$ ), post-emergence, at 20 days after emergence (DAE), in both cultures. Cover nitrogen fertilization was performed at 32 and 35 DAE manually, distributing the fertilizer on the soil surface (without incorporation), next to and approximately $8 \mathrm{~cm}$ from the sowing lines. After the cover fertilization was completed, the area was irrigated by spraying (14 mm blade) at night to minimize $\mathrm{N}$ losses by volatilization of ammonia, which is common in irrigated wheat cultivation. The harvest was done manually at 110 DAE of the wheat, in the two harvests.

The wheat grain yield was determined by collecting the plants contained in the useful area of each plot, the grains mechanically separated from the spikelet and the yield quantified later, with the data transformed to bags of $60 \mathrm{~kg}$ and corrected to $13 \%$ of humidity (base humid). The results were submitted to analysis of variance and Tukey's test at 5\% probability for comparison of means of $\mathrm{N}$ sources and with or without Azospirillum brasilense inoculation, and adjusted to the regression equations for the effect of $\mathrm{N}$ doses, using the program SISVAR.

For the economic analysis, the structure based on the total operational cost (TOC) of production used by the Institute of Agricultural Economics (IEA) was implemented, according to Matsunaga et al. (1976), which is made up of the sum of costing expenses including performed operations, inputs (fertilizers, seeds, pesticides, etc.), labor, machinery, and irrigation, and referred to as the effective operational cost (EOC). In this study, other costs and interest costs were taken into consideration at $5 \%$ of the EOC, resulting, therefore, in the total operational cost (TOC), which was extrapolated to one hectare.

To determine the profitability of the treatments involved, profitability analyzes were performed according to Martin et al. (1998). For this purpose, gross revenue $(\mathrm{GV})$ in BRL, as the quantity of the product produced (in number of $60 \mathrm{~kg}$ bags) was determined by the average selling price in BRL. Operating income (OI) was calculated as the difference between gross revenue and total operating cost; accumulated operating profit (AOP), as the sum of OI obtained in the 2 years of study; profitability index (PI) was obtained as the ratio between operating income (OI) and gross revenue (GV), expressed as a percentage; equilibrium price, given a certain level of total operational cost of production, as the minimum price to be obtained to cover this cost, given the average productivity of the producer; and equilibrium productivity, given a certain level of total operating cost of production, was calculated as the minimum productivity to cover this cost, given the average value paid to the producer.

The average prices were collected in the region of Selvíria - MS, in the years 2014 and 2015 (IEA, 2016). In this study, simulations were made as if each treatment of the experiment represented a commercial crop, considering the values paid for the inputs for the 2015 harvest. To facilitate the discussion, the values referring to the productivities were transformed into bags of $60 \mathrm{~kg}$, since this is the basic marketing unit for local producers. The value of the wheat bag in the municipality of Selvíria MS was 40.00 BRL per unit produced. Regarding N sources, the value paid by the farmer was $1,780.00$ BRL and 2,000.00 BRL per ton respectively for urea and urea with urease inhibitor. For the Azospirillum brasilense inoculant, the price was 10.00 BRL per dose, and three doses per hectare were used in the two growing seasons. It is worth mentioning that the sale values of wheat and nitrogen fertilizers used were based on the average price received by the producer over the last 3 years. 


\section{Results and Discussion}

\section{Productivity of wheat grains}

Conventional urea and Super N showed similar results in wheat grain yield (Table 1), which agree with Megda et al. (2009) and Theago et al. (2014). Prando et al. (2012), evaluating sources of urea, urea + NBPT, and coated urea in temperate climatic conditions, did not observe changes in yield, grain mass, number of spikes per $\mathrm{m}^{2}$, and plant height, but partially obtained results similar to the present study. It is worth noting that $\mathrm{N}$ sources may have presented similar behavior because of the use of irrigation during the whole crop cycle, which would have reduced volatilization losses, mainly in the form of $\mathrm{NH}_{3}$, which occur in a higher proportion in the first days after application of urea.

Table 1. Productivity of wheat grains as a function of $\mathrm{N}$ doses and sources and inoculation with Azospirillum brasilense recorded at Selvíria - MS in 2014 and 2015.

\begin{tabular}{ccc}
\hline \multirow{2}{*}{$\mathrm{N}^{*}{ }^{-1}$ Goses $\left(\mathrm{kg} \mathrm{ha}^{-1}\right)$} & 2014 & 2015 \\
\cline { 2 - 3 } & 37.8 & 31.8 \\
0 & 50.1 & 50.5 \\
100 & 52.2 & 56.1 \\
150 & 54.4 & 52.8 \\
200 & 52.7 & 54.4 \\
\hline Source of N & \\
\hline Urea & $49.3 \mathrm{a}$ & $48.8 \mathrm{a}$ \\
Super N & $49.6 \mathrm{a}$ & $49.3 \mathrm{a}$ \\
M.D.S. (5\%) & 3.8 & 3.5 \\
\hline Inoculation & & \\
\hline With Azospirillum & 49.9 & 50.1 \\
Without Azospirillum & 49.0 & 48.1 \\
M.D.S. (5\%) & 3.8 & 3.5 \\
\hline General average & 49.4 & 49.1 \\
C.V. (\%) & 17.12 & 16.08 \\
\hline
\end{tabular}

Means followed by the same letter, in the column, do not differ among themselves by the Tukey's test at 5\% probability.

${ }^{1}$ bag of $60 \mathrm{~kg}$ of wheat.

The interaction between doses and inoculation with $A$. brasilense was significant for grain yield in the years 2014 and 2015. In 2014, at a $150 \mathrm{~kg} \mathrm{ha}^{-1}$ $\mathrm{N}$ dose, inoculation provided higher productivity than non-inoculated treatment (Table 2). The grain yield of wheat in 2014 increased linearly with $\mathrm{N}$ doses in treatments without inoculation and the quadratic function was adjusted for the inoculated treatments, with a positive response up to the 139 $\mathrm{kg} \mathrm{ha}^{-1} \mathrm{~N}$ dose. In 2015, in the $100 \mathrm{~kg} \mathrm{ha}^{-1} \mathrm{~N}$ dose, inoculation provided higher productivity than the non-inoculated treatment (Table 2). The grain yield in 2015 adjusted to the quadratic function for doses in the treatments with and without inoculation with A. brasilense, with a positive response up to 142 and $134 \mathrm{~kg} \mathrm{ha}^{-1}$ of $\mathrm{N}$, respectively. The $\mathrm{N}$ doses mentioned above to obtain the maximum yield of grains were high, because the wheat was cultivated on the maize stover, that is, part of the $\mathrm{N}$ that was applied could have been used by immobilized decomposers and/ or mineralizing soil microorganisms (ACOSTA et al., 2014), since the higher the $\mathrm{C} / \mathrm{N}$ ratio of the stover, the longer the $\mathrm{N}$ release time of the vegetal residue, and consequently $\mathrm{N}$ demand will be higher for the mineral fertilizer. 
Table 2. Deployment of the inoculation interaction and $\mathrm{N}$ doses of the analysis of variance referring to grain yield of wheat studied at Selvíria - MS in 2014 and 2015.

\begin{tabular}{|c|c|c|c|c|c|}
\hline \multirow{3}{*}{ Inoculation $^{1}$} & \multicolumn{5}{|c|}{ Year 2014} \\
\hline & \multicolumn{5}{|c|}{ N Doses $\left(\mathrm{kg} \mathrm{ha}^{-1}\right)$} \\
\hline & 0 & 50 & 100 & 150 & 200 \\
\hline With $^{* *}$ & $36.6 \mathrm{a}$ & $48.6 \mathrm{a}$ & $53.4 \mathrm{a}$ & $59.1 \mathrm{a}$ & $52.0 \mathrm{a}$ \\
\hline Without** & $39.0 \mathrm{a}$ & $51.5 \mathrm{a}$ & $51.0 \mathrm{a}$ & $49.8 \mathrm{~b}$ & $53.4 \mathrm{a}$ \\
\hline M.D.S. & \multicolumn{5}{|c|}{8.5} \\
\hline Inoculation $^{2}$ & \multicolumn{5}{|c|}{ Year 2015} \\
\hline With $^{* *}$ & $27.9 \mathrm{a}$ & $50.6 \mathrm{a}$ & $61.1 \mathrm{a}$ & $52.8 \mathrm{a}$ & $58.3 \mathrm{a}$ \\
\hline Without ${ }^{* *}$ & $35.7 \mathrm{a}$ & $50.3 \mathrm{a}$ & $51.1 \mathrm{~b}$ & $52.8 \mathrm{a}$ & $50.5 \mathrm{a}$ \\
\hline M.D.S. & \multicolumn{5}{|c|}{7.9} \\
\hline
\end{tabular}

Means followed by the same letters, in the column, do not differ among themselves by the Tukey's test at 5\% probability.

** significant at $\mathrm{p}<0.01 ; \quad *$ significant at $0.01<\mathrm{p}<0.05$; ns: not significant

${ }^{1} \hat{Y}$ with $=36.3594+0.2957 \mathrm{x}-0.00106 \mathrm{x}^{2}\left(\mathrm{R}^{2}=0.97\right.$ and $\left.\mathrm{PM}=138.6 \mathrm{~kg} \mathrm{ha}^{-1}\right)$

$\hat{Y}$ without $=43.5478+0.0540 \mathrm{x}\left(\mathrm{R}^{2}=0.56\right)$

${ }^{2} \hat{Y}$ with $=29.9050+0.4302 \mathrm{x}-0.00152 \mathrm{x}^{2}\left(\mathrm{R}^{2}=0.87\right.$ and $\left.\mathrm{PM}=141.5 \mathrm{~kg} \mathrm{ha}^{-1}\right)$

$\hat{Y}$ without $=36.9534+0.2516 \mathrm{x}-0.00094 \mathrm{x}^{2}\left(\mathrm{R}^{2}=0.92\right.$ and $\left.\mathrm{PM}=134.1 \mathrm{~kg} \mathrm{ha}^{-1}\right)$.

The inoculation with $A$. brasilense in association with the $\mathrm{N}$ doses in the $140 \mathrm{~kg} \mathrm{ha}^{-1}$ range provided the maximum yield of the wheat crop in both years of the study. In contrast, in the absence of inoculation, the magnitude of response to $\mathrm{N}$ doses was higher, because in the first year there was adjustment to the increasing linear function (Table 2). It is also worth noting that the estimated productivity of the inoculated treatments was higher, numerically, in most of the doses tested in the two cultures (in 2014 at 100 and 150 and in 2015 at 100 and 200 $\mathrm{kg} \mathrm{ha}^{-1}$ of $\mathrm{N}$ doses), even using $\mathrm{N}$ doses considered high, evidencing the benefit of inoculation with $A$. brasilense in the irrigated wheat crop. A possible explanation, reported by Bashan et al. (2004), is that production of plant hormones, mainly indoleacetic acid (IAA) by bacteria of the genus Azospirillum, plays an essential role in the promotion of plant growth and, according to Hungria et al. (2010), may improve the absorption of several macro and micronutrients, increasing the efficiency of the use of the available nutrients, as an increased development of the root system of the plants inoculated with this bacterium may have occurred.

Regarding grain yield, several authors also reported a positive response to nitrogen fertilization in wheat crop (CAZETTA et al., 2007; TEIXEIRA
FILHO et al., 2007, 2008, 2010a; POVH et al., 2008). In similar climatic conditions for the cultivation of wheat as winter crop in the low altitude Cerrado region, Cazetta et al. (2007) predicted maximum grain yield at $78 \mathrm{~kg} \mathrm{ha}^{-1} \mathrm{~N}$ dose, Teixeira Filho et al. $(2007,2008)$ at the $90 \mathrm{~kg} \mathrm{ha}^{-1} \mathrm{~N}$ dose, and Teixeira Filho et al. (2010a) at $120 \mathrm{~kg} \mathrm{ha}^{-1}$ $\mathrm{N}$ dose. This difference in the $\mathrm{N}$ rates that provide the maximum yield of wheat grains is due to the different requirement of each genotype, as well as the variation in the edaphoclimatic conditions of these surveys, for example as a function of climatic conditions, predecessor crops, and cropping systems.

In relation to inoculation with $A$. brasilense, positive and similar results were reported by Lemos et al. (2013), studying five cultivars of wheat (CD 104, CD 108, CD 119, CD 120, and CD 150) with and without inoculation and associated with $\mathrm{N}$ doses. According to these authors, the response to inoculation with $A$. brasilense in culture of wheat occurs satisfactorily when carried out in conjunction with nitrogen fertilization, elucidating that $A$. brasilense assists in the development of the plant with a reflection on crop productivity, not as a substitute for nitrogen fertilization, but as a complement, allowing to reduce the $\mathrm{N}$ dose to be 
applied. This has been verified and mentioned in the current study carried out at low altitudes in the Cerrado.

On the other hand, Ferreira et al. (2014), analyzing the foliar application of $A$. brasilense and $\mathrm{N}$ doses as top-dressing in wheat cultivations in the Cerrado, observed that the inoculation did not influence plant height, number of spikes per $\mathrm{m}^{2}$ and grain per spike, hectoliter mass, mass of 1,000 grains, and grain yield. Likewise, Nunes et al. (2015) studying inoculation with $A$. brasilense in soils with high and low availability of $\mathrm{N}$ and Galindo et al. (2015) studying times of application of $A$. brasilense via leaf also did not observe any effect of inoculation on the productive components and wheat grains yield. It is worth mentioning that bacteria of the genus Azospirillum are native to the soil (SALA et al., 2007), so it is possible that these were found in high densities in the soils under study and, thus, emulating the effect of inoculation. In addition, the affinity of the cultivar to the strains of this diazotrophic bacterium may vary and determine whether or not the inoculation is successful.

Therefore, there is still high divergence in the use of $A$. brasilense in the wheat crop and even in other grasses, due to the very variable results with inoculation. However, it is important to highlight the importance of research on the subject and the potential of using this technology, mainly because it is inexpensive and easy to apply, and with great potential to increase the efficiency of nitrogen fertilizers, since the $\mathrm{N}$ dose can be reduced when associated with $A$. brasilense inoculation. Therefore, it is possible to produce wheat in a more sustainable way, justifying an analysis of the economic viability of the application of this bacterium allied to the $\mathrm{N}$ doses.

\section{Economic analysis}

Table 3 shows the structure of the total operational cost (TOC) in the wheat crop, in the municipality of Selvíria - MS. The treatment at $0 \mathrm{~kg} \mathrm{ha}^{-1}$ dose of urea without inoculation is described. This model of TOC structure was used in all treatments.

It can be seen from the data in Table 3 that the costs of mechanized operations, followed by fertilizers, were the highest, corresponding to 43.6 and $35.7 \%$ of the TOC, respectively, corroborating with Kaneko et al. (2010), who studied the economic viability of the maize crop in the Selviria - MS region and found higher releases with fertilizers and mechanized operations, corresponding to $32.74 \%$ and $30.91 \%$ of the TOC. It is noteworthy that with an increase in the nitrogen dose applied and a change in the source of $\mathrm{N}$ taken into consideration, our results show an increasing trend in the percentage of expenses in relation to the TOC of the fertilizers.

The costs of nitrogen fertilization in cover, due to the increasing $\mathrm{N}$ doses, ranged from 9.84 to $30.39 \%$ of the TOC for urea and from 10.92 to $32.90 \%$ for Super N. Kaneko et al. (2015), working with N doses $\left(0,45,90,135\right.$, and $180 \mathrm{~kg} \mathrm{ha}^{-1}$ in cover $)$, and two sources (urea and coated urea), with and without inoculation with $A$. brasilense in the Maize crop, obtained costs, with sowing fertilization, in the first harvest and second harvest, that were 31.80 and $24.16 \%$ of the TOC, respectively. For the costs of nitrogen fertilization, the values varied between 12 and 14 and 16 and $18 \%$ with urea and coated urea, respectively, in both crops. Gitti et al. (2012), studying the economic viability of the wheat crop for the low altitude Cerrado region, under no-tillage system with different green fertilizers and nitrogen doses $\left(0,25,50,75\right.$, and $\left.125 \mathrm{~kg} \mathrm{ha}^{-1}\right)$ reported that the expenditure with fertilization was $23.52 \%$ of the TOC, for yields ranging from 34.5 and $66.5 \mathrm{bag}$ $\mathrm{ha}^{-1}$, and cost with nitrogen fertilization in cover, as a function of increasing doses, varied from 4.85 to $20.29 \%$ of TOC. 
Table 3. Estimated total operational cost (TOC) of wheat for treatment with urea source at $0 \mathrm{~kg} \mathrm{ha}^{-1}$ dose without and with inoculation of $A$. brasilense in one hectare at Selvíria - MS in 2014 and 2015.

\begin{tabular}{|c|c|c|c|c|c|}
\hline Description & Specification $^{1}$ & No. of times & Coefficient & $\begin{array}{c}\text { Unitary Value } \\
\text { (BRL) }\end{array}$ & $\begin{array}{c}\text { Total Value } \\
\text { Total (BRL) }\end{array}$ \\
\hline \multicolumn{6}{|l|}{ A. MECHANIZED OPERATIONS } \\
\hline Liming & MH & 1.00 & 0.30 & 85.00 & 25.50 \\
\hline Desiccation & MH & 1.00 & 0.50 & 85.00 & 42.50 \\
\hline Clearing (triton) & MH & 1.00 & 0.50 & 85.00 & 42.50 \\
\hline Sowing & MH & 1.00 & 0.60 & 150.00 & 90.00 \\
\hline Pulverization & MH & 2.00 & 0.60 & 85.00 & 102.00 \\
\hline Coating Fertilizer & MH & 1.00 & 0.40 & 150.00 & 60.00 \\
\hline Harvest & $\mathrm{MH}$ & 1.00 & 1.00 & 118.00 & 118.00 \\
\hline Irrigation (pivot) & $\mathrm{mm}$ & 1.00 & 150.00 & 2.50 & 375.00 \\
\hline Subtotal A & & & & & 855.50 \\
\hline \multicolumn{6}{|l|}{ B - Supplies } \\
\hline Dolomite Limestone & $\mathrm{t}$ & 1.00 & 0.63 & 85.00 & 53.13 \\
\hline Fertilizer 08-28-16 & $\mathrm{t}$ & 1.00 & 0.35 & $1,998.00$ & 699.30 \\
\hline Urea & $\mathrm{t}$ & 1.00 & 0.00 & $1,780.00$ & 0.00 \\
\hline Inoculant (A. brasilense) & L & 1.00 & 0.00 & 10.00 & 0.00 \\
\hline Wheat Seed CD 116 & $50 \mathrm{~kg}$ bag & 1.00 & 1.10 & 45.00 & 49.50 \\
\hline Herbicide glyphosate & $\mathrm{L}$ & 1.00 & 4.00 & 14.51 & 58.04 \\
\hline Herbicide 2,4-D & $\mathrm{L}$ & 1.00 & 1.00 & 13.24 & 13.24 \\
\hline Carbendazim + Thiran & $\mathrm{L}$ & 1.00 & 0.20 & 46.42 & 9.28 \\
\hline Imidacloprid + Thiodicarb & $\mathrm{L}$ & 1.00 & 0.30 & 236.32 & 70.90 \\
\hline Metsulfuron methyl & $\mathrm{g} \mathrm{ha}^{-1}$ & 1.00 & 3.00 & 1.02 & 3.05 \\
\hline Subtotal B & & & & & 956.44 \\
\hline Effective operational cost (EOC) & & & & & $1,811.94$ \\
\hline Other costs & & & & & 90.60 \\
\hline Costing interest & & & & & 58.89 \\
\hline Total operational cost (TOC) & & & & & $1,961.42$ \\
\hline
\end{tabular}

Regarding TOC and productivity of the evaluated treatments (Table 4), the highest value for TOC (BRL 2,956.12) was obtained for the treatment using the Super N source at the $200 \mathrm{~kg}$ $\mathrm{ha}^{-1}$ of $\mathrm{N}$ dose, inoculated with $A$. brasilense. The lowest value corresponds to the treatments without nitrogen fertilization in the cover $\left(0 \mathrm{~kg} \mathrm{ha}^{-1}\right)$ and without inoculation with $A$. brasilense, with TOC in the amount of BRL 1,961.42. However, as nutrient extraction takes place, the soil $\mathrm{N}$ stocks are depleted and if this is not restored to the soil, it may compromise crop productivity over time. It was verified that the TOC of the treatments that did not receive nitrogen fertilization $\left(0 \mathrm{~kg} \mathrm{ha}^{-1}\right)$ presented equal values, independently of the source. This was because in the absence of nitrogen fertilization the relative cost for nitrogen fertilizer is equal to 0 for both sources. Regarding productivity, the highest values were recorded in the treatments where the crop was fertilized with the Super N source at a dose of $150 \mathrm{~kg} \mathrm{ha}^{-1}$ and were inoculated with A. brasilense in the $2013 / 14$ harvest, and in the treatments where urea was the source of fertilizer applied at a dose of $100 \mathrm{~kg} \mathrm{ha}^{-1}$ to crops that were inoculated in the 2014/15 harvest and presented an average productivity of approximately 65 and 61 bags of $60 \mathrm{~kg}$, respectively (Table 4). 
Table 4. Total operational cost (TOC), grain yield (PROD), and gross revenue (GV) of wheat crop as a function of doses, sources, and inoculation with Azospirillum brasilense at Selvíria MS in 2014 and 2015.

\begin{tabular}{|c|c|c|c|c|c|c|c|c|c|c|}
\hline \multicolumn{11}{|c|}{ Without Azospirillum brasilense } \\
\hline & \multicolumn{5}{|c|}{ Urea } & \multicolumn{5}{|c|}{ Super N } \\
\hline & & 2013/14 & $2014 / 15$ & $2013 / 14$ & $2014 / 15$ & & 2013/14 & $2014 / 15$ & $2013 / 14$ & $2014 / 15$ \\
\hline \multirow[t]{2}{*}{ Doses } & TOC & \multicolumn{2}{|c|}{ PROD } & \multicolumn{2}{|c|}{$\mathrm{GV}$} & TOC & \multicolumn{2}{|c|}{ PROD } & \multicolumn{2}{|c|}{$\mathrm{GV}$} \\
\hline & BRL & \multicolumn{2}{|c|}{$60 \mathrm{~kg} \mathrm{ha}^{-1} \mathrm{bag}$} & \multicolumn{3}{|c|}{ 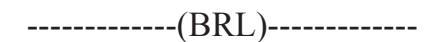 } & \multicolumn{2}{|c|}{$60 \mathrm{~kg} \mathrm{ha}^{-1}$ bag } & \multicolumn{2}{|c|}{ BRL } \\
\hline 0 & $1,961.42$ & 38.30 & 32.44 & $1,532.11$ & $1,297.45$ & $1,961.42$ & 39.75 & 38.93 & $1,589.96$ & $1,557.37$ \\
\hline 50 & $2,175.52$ & 55.44 & 50.40 & $2,217.44$ & $2,015.86$ & $2,201.98$ & 47.61 & 50.19 & $1,904.60$ & $2,007.58$ \\
\hline 100 & $2,389.61$ & 52.98 & 51.36 & $2,119.19$ & $2,054.43$ & $2,442.34$ & 49.01 & 50.74 & $1,960.42$ & $2,029.50$ \\
\hline 150 & $2,603.71$ & 54.38 & 54.05 & $2,175.08$ & $2,192.13$ & $2,683.09$ & 45.25 & 51.47 & $1,810.05$ & $2,058.92$ \\
\hline 200 & $2,817.80$ & 55.02 & 51.97 & $2,200.65$ & $2,078.26$ & $2,923.65$ & 51.75 & 49.00 & $2,070.12$ & $1,960.15$ \\
\hline Average & $2,389.61$ & 51.22 & 48.04 & $2,048.89$ & $1,927.63$ & $2,442.50$ & 46.67 & 48.07 & $1,867.03$ & $1,922.70$ \\
\hline \multicolumn{11}{|c|}{ With Azospirillum brasilense } \\
\hline & \multicolumn{5}{|c|}{ Urea } & \multicolumn{5}{|c|}{ Super N } \\
\hline & & $2013 / 14$ & $2014 / 15$ & $2013 / 14$ & $2014 / 15$ & & 2013/14 & $2014 / 15$ & $2013 / 14$ & $2014 / 15$ \\
\hline \multirow[t]{2}{*}{ Doses } & TOC & \multicolumn{2}{|c|}{ PROD } & \multicolumn{2}{|c|}{$\mathrm{GV}$} & TOC & \multicolumn{2}{|c|}{ PROD } & \multicolumn{2}{|c|}{$\mathrm{GV}$} \\
\hline & BRL & \multicolumn{2}{|c|}{$60 \mathrm{~kg} \mathrm{ha}^{-1}$ bag } & \multicolumn{3}{|c|}{--------------(BRL)-------------- } & \multicolumn{2}{|c|}{$60 \mathrm{~kg} \mathrm{ha}^{-1} \mathrm{bag}$} & \multicolumn{2}{|c|}{ BRL } \\
\hline 0 & $1,993.90$ & 37.08 & 28.21 & $1,483.30$ & $1,128.44$ & $1,993.90$ & 36.13 & 27.50 & $1,445.26$ & $1,100.01$ \\
\hline 50 & $2,207.99$ & 45.57 & 52.03 & $1,822.97$ & 2.081 .34 & $2,234.45$ & 51.62 & 49.17 & $2,064.67$ & $1,966.83$ \\
\hline 100 & $2,422.09$ & 48.61 & 61.20 & $1,944.55$ & $2,448.16$ & $2,475.01$ & 58.23 & 60.91 & $2,329.11$ & $2,436.25$ \\
\hline 150 & $2,636.18$ & 53.59 & 50.36 & $2,143.47$ & $2,014.54$ & $2,715.57$ & 64.53 & 55.22 & $2,581.22$ & $2,208.67$ \\
\hline 200 & $2,850.28$ & 52.19 & 56.34 & $2,087.53$ & $2,253.69$ & $2,956.12$ & 51.78 & 60.23 & $2,071.03$ & $2,409.01$ \\
\hline Average & $2,422.09$ & 47.41 & 49.63 & $1,896.36$ & $1,985.23$ & $2,475.01$ & 52.46 & 50.61 & $2,098.26$ & $2,024.15$ \\
\hline
\end{tabular}

* Commercial price of wheat: BRL 40.00 per bag.

Regarding the gross revenue per hectare obtained for the different combinations of treatments in the two harvests studied, it was observed that when wheat prices are constant, gross revenue for different treatments follow the same trend as productivities (Table 4), that is, increases in revenue occur due to the increase in grain yield. This result is in agreement with Silva et al. (2007) and Duete et al. (2009), according to which productivity is a prime factor to ensure good profitability for the producer. According to Duete et al. (2009), even in regions where the producer gets good grain prices, if productivity is low, profitability is compromised. Thus, investment in management practices, such as balanced nitrogen fertilization, increases grain yield and gross margin of planted crops, regardless of location.

For the values referring to the operating profit, in the 2013/2014 harvest (Table 5), OP was negative for all treatments, regardless of dose, source, or presence of inoculation, except at $50 \mathrm{~kg}$ $\mathrm{ha}^{-1}$ dose with urea as source and in the absence of inoculation, where the OP obtained was BRL 41.92. Similarly, in the $2014 / 2015$ harvest, the OP was negative (there were losses) in most of the treatments studied, except for the application of $100 \mathrm{~kg} \mathrm{ha}^{-1}$ of urea with inoculation, giving an OP of BRL 26.07 (Table 5). These results agree with those obtained by Gomes et al. (2007), who studied $\mathrm{N}$ doses in cover $\left(25,50,100\right.$, and $\left.150 \mathrm{~kg} \mathrm{ha}^{-1}\right)$ with urea as source and obtained a negative profitability regardless of the applied dose. This variation among crops occurred mainly because of the unfavorable climatic conditions, with high temperatures and the lack of rainfall in the region, which during the two years of our study were attenuated with the use of irrigation. 
Table 5. Operating profit (OP) and profitability index (PI) of wheat crop as a function of doses, sources, and inoculation with Azospirillum brasilense at Selvíria MS in 2014 and 2015.

\begin{tabular}{|c|c|c|c|c|c|c|c|c|}
\hline \multicolumn{9}{|c|}{ Without Azospirillum brasilense } \\
\hline & \multicolumn{6}{|c|}{ Urea } & \multicolumn{2}{|c|}{ Super N } \\
\hline & $2013 / 14$ & $2014 / 15$ & $2013 / 14$ & $2014 / 15$ & $2013 / 14$ & $2014 / 15$ & $2013 / 14$ & $2014 / 15$ \\
\hline Doses & \multicolumn{2}{|c|}{ OP } & \multicolumn{2}{|c|}{ PI } & \multicolumn{2}{|c|}{ OP } & \multicolumn{2}{|c|}{ PI } \\
\hline & \multicolumn{2}{|c|}{ BRL } & \multicolumn{2}{|c|}{--------(\%)-------- } & \multicolumn{2}{|c|}{ BRL } & \multicolumn{2}{|c|}{-------- (\%)-------- } \\
\hline 0 & -429.31 & -663.97 & -28.02 & -51.18 & -371.47 & -404.06 & -23.36 & -25.94 \\
\hline 50 & 41.92 & -159.66 & 1.89 & -7.92 & -297.39 & -194.41 & -15.61 & -9.68 \\
\hline 100 & -270.42 & -335.19 & -12.76 & -16.32 & -481.93 & -412.84 & -24.58 & -20.34 \\
\hline 150 & -428.63 & -441.58 & -19.71 & -20.42 & -873.04 & -624.17 & -48.23 & -30.32 \\
\hline 200 & -617.15 & -739.14 & -28.04 & -35.56 & -853.54 & -963.50 & -41.23 & -49.15 \\
\hline Average & -340.718 & -467.91 & -17.33 & -26.28 & -575.47 & -519.80 & -30.60 & -27.09 \\
\hline \multicolumn{9}{|c|}{ With Azospirillum brasilense } \\
\hline & \multicolumn{6}{|c|}{ Urea } & \multicolumn{2}{|c|}{ Super N } \\
\hline & $2013 / 14$ & $2014 / 15$ & $2013 / 14$ & $2014 / 15$ & $2013 / 14$ & $2014 / 15$ & $2013 / 14$ & $2014 / 15$ \\
\hline Doses & \multirow{2}{*}{\multicolumn{2}{|c|}{$\begin{array}{c}\text { OP } \\
\text { BRL }\end{array}$}} & \multicolumn{2}{|c|}{ PI } & \multicolumn{2}{|c|}{$\mathrm{OP}$} & \multicolumn{2}{|c|}{ PI } \\
\hline & & & \multicolumn{2}{|c|}{--------(\%)-------- } & \multicolumn{2}{|c|}{ BRL } & \multicolumn{2}{|c|}{-------- (\%)-------- } \\
\hline 0 & -510.60 & -865.46 & -34.42 & -76.70 & -548.64 & -893.89 & -37.96 & -81.26 \\
\hline 50 & -385.02 & -126.65 & -21.12 & -6.09 & -169.68 & -267.62 & -8.22 & -13.61 \\
\hline 100 & -477.54 & 26.07 & -24.56 & 1.06 & -145.91 & -38.77 & -6.26 & -1.59 \\
\hline 150 & -492.71 & -621.64 & -22.99 & -30.86 & -134.35 & -506.90 & -5.20 & -22.95 \\
\hline 200 & -762.75 & -596.59 & -36.54 & -26.47 & -885.10 & -547.12 & -42.74 & -22.71 \\
\hline Average & -525.72 & -436.85 & -27.93 & -27.81 & -376.74 & -450.86 & -20.08 & -28.42 \\
\hline
\end{tabular}

In the 2013/14 crop, the highest OP was obtained using urea at $50 \mathrm{~kg} \mathrm{ha}^{-1}$ dose without inoculation with A. brasilense (BRL 41.92). For the 2014/15 crop, the highest OP was provided by the use of urea at $100 \mathrm{~kg} \mathrm{ha}^{-1}$ dose together with the inoculation with $A$. brasilense (BRL 26.07) and, although it was the best result obtained in this harvest, it was much lower compared to the previous harvest (Table 5). Even in the absence of nitrogen fertilization in the cover (both urea and Super N) in the absence or presence of inoculation with $A$. brasilense, wheat cultivation would not be feasible after maize due to the losses obtained with these yield levels of grains.

Aguiar et al. (2008) found a positive effect of maize marketed in April 2007, cultivated under no-tillage system, without nitrogen fertilization, which is partially different from what was observed in this study. Similarly, Kaneko et al. (2015) obtained positive OP in the maize crop, without and with inoculation, ranging from BRL 1,178.30 to BRL 1,783.9 and BRL 763.00 to BRL 1,617.40, respectively. Moreover, Sabundjian et al. (2014) studied the $\mathrm{N}$ doses $\left(0,40,80\right.$, and $\left.120 \mathrm{~kg} \mathrm{ha}^{-1}\right)$ in cover of irrigated winter bean crop, with different cover vegetation inoculated with $A$. brasilense, and obtained a positive gain margin of BRL 515.81 and BRL 2,425.4 with 40 and $80 \mathrm{~kg} \mathrm{ha}^{-1}$ doses, respectively, for the treatments with $A$. brasilense applied in the predecessor vegetal cover, reinforcing the issue that it would not be economically viable to plant wheat, compared to the crops of safflower, corn, and winter bean, planted at the same wheat season in the region, due to the greater profitability of other crops.

Table 5 shows that the profitability index (PI), followed the same trend of operating profit. In the 2013/14 harvest, the treatment with the urea at $50 \mathrm{~kg}$ ha $^{-1}$ dose without $A$. brasilense provided PI of $1.89 \%$. For the 2014/15 crop, the application of urea at 100 $\mathrm{kg} \mathrm{ha} \mathrm{a}^{-1}$ dose to crops that were inoculated provided 
PI of $1.06 \%$. Teixeira Filho et al. (2010b), studying $\mathrm{N}$ doses $\left(0,50,100,150\right.$, and $\left.200 \mathrm{~kg} \mathrm{ha}^{-1}\right)$, sources (ammonium sulfonitrate, ammonium sulfate, and urea) and wheat cultivars (E21 and IAC 370) in the low altitude Cerrado in irrigated cultivation, obtained higher gross margin of gain with $50 \mathrm{~kg} \mathrm{ha}^{-1}$ dose in cover, however urea gave lower values of gain compared to ammonium sulfate, presenting values close to BRL 550 and BRL 500, respectively. Gitti et al. (2012), obtained a higher cost-benefit ratio, because of different plant covers, in doses between 50 and $75 \mathrm{~kg} \mathrm{ha}^{-1}$, values that were in agreement with the doses that provided higher PI in the two crops evaluated in the present study.

Silva et al. (2005), working with $\mathrm{N}$ doses (30, $60,90,120$, and $\left.180 \mathrm{~kg} \mathrm{ha}^{-1}\right)$ in cover, in no-tillage maize culture in the Cerrado region obtained PI between 12.62 and $21.51 \%$, while in the absence of nitrogen fertilization, PI was $-17.37 \%$, reinforcing the importance of nitrogen fertilization management to obtain profitability with cereal crops. In contrast,
Kaneko et al. (2015) obtained PI ranging from 42.36 to 51.56 and 42.36 and 52.71 and between 39.80 and 57.84 and 41.41 and $57.84 \%$ with urea and coated urea sources without and with $A$. brasilense inoculation, according to the applied doses of fertilizer at 0,45 , 90,135 , and $180 \mathrm{~kg} \mathrm{ha}^{-1}$. These values were higher than those seen in the present study.

In the absence of inoculation, the highest OP was obtained, regardless of the source used, at the $50 \mathrm{~kg} \mathrm{ha}^{-1}$ dose (BRL -117.74 and BRL -491.80, respectively for urea and Super $\mathrm{N}$ ). When the treatments were inoculated with $A$. brasilense, the highest OP (BRL -451.57) was obtained at $100 \mathrm{~kg}$ $\mathrm{ha}^{-1}$ dose using urea as the fertilizer. For Super N with inoculation, the highest OP occurred when the dose of $50 \mathrm{~kg} \mathrm{ha}^{-1}$ was applied, giving a value of BRL -437.30. There is a negative OP at the end of the 2 years of evaluation, which was regardless of the source and dose applied, as well as inoculation with $A$. brasilense (Table 6).

Table 6. Accumulated operating profit (AOP), equilibrium price (EQP), and equilibrium productivity (EQPROD) of wheat crop as a function of doses, sources, and inoculation with Azospirillum brasilense at Selvíria MS in 2014 and 2015.

\begin{tabular}{|c|c|c|c|c|c|c|c|c|c|c|}
\hline \multicolumn{11}{|c|}{ Without Azospirillum brasilense } \\
\hline & \multicolumn{5}{|c|}{ Urea } & \multicolumn{5}{|c|}{ Super N } \\
\hline & & $2013 / 14$ & $2014 / 15$ & $2013 / 14$ & $2014 / 15$ & & $2013 / 14$ & $2014 / 15$ & $2013 / 14$ & $2014 / 15$ \\
\hline Doses & AOP & \multicolumn{2}{|c|}{ EQP } & \multicolumn{2}{|c|}{ EQPROD } & AOP & \multicolumn{2}{|c|}{ EQP } & \multicolumn{2}{|c|}{ EQPROD } \\
\hline & BRL & \multicolumn{2}{|c|}{ BRL bag ${ }^{-1}$} & \multicolumn{2}{|c|}{$60 \mathrm{~kg} \mathrm{ha}^{-1} \mathrm{bag}$} & BRL & \multicolumn{2}{|c|}{$\mathrm{BRL}_{\text {bag }^{-1}}$} & \multicolumn{2}{|c|}{$60 \mathrm{~kg} \mathrm{ha}^{-1} \mathrm{bag}$} \\
\hline 0 & $-1,093.28$ & 51.21 & 60.47 & 49.04 & 49.04 & -775.53 & 49.35 & 50.38 & 49.04 & 49.04 \\
\hline 50 & -117.74 & 39.24 & 43.17 & 54.39 & 54.39 & -491.8 & 46.25 & 43.87 & 55.05 & 55.05 \\
\hline 100 & -605.61 & 45.10 & 46.53 & 59.74 & 59.74 & -894.77 & 49.83 & 48.14 & 61.06 & 61.06 \\
\hline 150 & -870.21 & 47.88 & 48.17 & 65.09 & 65.09 & -1497.21 & 59.29 & 52.13 & 67.08 & 67.08 \\
\hline 200 & $-1,356.29$ & 51.22 & 54.22 & 70.45 & 70.45 & -1817.04 & 56.49 & 59.66 & 73.09 & 73.09 \\
\hline Average & -808.63 & 46.93 & 50.51 & 59.74 & 59.74 & -1095.27 & 51.18 & 50.84 & 58.06 & 58.06 \\
\hline \multicolumn{11}{|c|}{ With Azospirillum brasilense } \\
\hline & \multicolumn{5}{|c|}{ Urea } & \multicolumn{5}{|c|}{ Super N } \\
\hline & & $2013 / 14$ & $2014 / 15$ & $2013 / 14$ & $2014 / 15$ & & $2013 / 14$ & $2014 / 15$ & $2013 / 14$ & $2014 / 15$ \\
\hline & $\mathrm{AOP}$ & \multicolumn{2}{|c|}{ EQP } & \multicolumn{2}{|c|}{ EQPROD } & $\mathrm{AOP}$ & \multicolumn{2}{|c|}{ EQP } & \multicolumn{2}{|c|}{ EQPROD } \\
\hline & BRL & \multicolumn{2}{|c|}{$\mathrm{BRL}^{b_{a g}-1}$} & \multicolumn{2}{|c|}{$60 \mathrm{~kg} \mathrm{ha}^{-1} \mathrm{bag}$} & BRL & \multicolumn{2}{|c|}{$\mathrm{BRL}^{\text {bag }^{-1}}$} & \multicolumn{2}{|c|}{$60 \mathrm{~kg} \mathrm{ha}^{-1} \mathrm{bag}$} \\
\hline 0 & $-1,376.06$ & 53.77 & 70.68 & 49.85 & 49.85 & $-1,442.53$ & 55.18 & 72.51 & 49.85 & 49.85 \\
\hline 50 & -511.67 & 48.45 & 42.43 & 55.20 & 55.20 & -437.3 & 43.29 & 45.44 & 55.86 & 55.86 \\
\hline 100 & -451.47 & 49.82 & 39.57 & 60.55 & 60.55 & -184.68 & 42.51 & 40.64 & 61.88 & 61.88 \\
\hline 150 & $-1,114.35$ & 49.19 & 52.34 & 65.90 & 65.90 & -641.25 & 42.08 & 49.18 & 67.89 & 67.89 \\
\hline 200 & $-1,359.34$ & 54.62 & 50.59 & 71.26 & 71.26 & $-1,432.22$ & 57.09 & 49.08 & 73.90 & 73.90 \\
\hline Average & -962.58 & 51.17 & 51.12 & 60.55 & 60.55 & -827.60 & 48.03 & 51.37 & 61.88 & 61.88 \\
\hline
\end{tabular}


In relation to equilibrium productivity (minimum productivity required to cover costs), it can be seen in Table 6 that, for the price of BRL 40.00 per bag of $60 \mathrm{~kg}$ of wheat, when the source used was Super N, at a dose of $200 \mathrm{~kg} \mathrm{ha}^{-1}$ with inoculation with $A$. brasilense, the equilibrium productivity was higher, being $73.90 \mathrm{bag}^{\mathrm{ha}} \mathrm{ha}^{-1}$, while at the same dose of $200 \mathrm{~kg} \mathrm{ha}^{-1}$ of Super $\mathrm{N}$ in absence of inoculation, the equilibrium price remained very close, with 73.09 bag ha $^{-1}$. Without the application of nitrogen fertilizer, regardless of the source used, the lowest equilibrium productivity was observed, which were 49.04 and 49.85 bag ha $^{-1}$, without and with inoculation with $A$. brasilense, respectively. Although lower equilibrium productivity was obtained in the absence of nitrogen fertilization, it is emphasized that the non-supply of $\mathrm{N}$ in cultivated soils may lead to their decrease in the soil over the years, thus compromising success of the activity. Lack of nutrient replacement in the long term would culminate in greater investment to build soil fertility lost through inadequate nutrient management. Regarding the inoculation, there was a variation in the equilibrium productivity between the uninoculated and inoculated treatments, at the same doses and sources applied, which is due to the low cost of inoculants and inoculation (BRL 10.00 per dose), which shows the benefits of inoculation.

Table 6 shows the values (in BRL) of the $60 \mathrm{~kg}$ bag of wheat, for the equilibrium price (minimum price to cover TOC). Grains that were produced using urea as the source obtained a lower equilibrium price when compared to those produced using Super $N$, in both $2013 / 14$ and $2014 / 15$. In relation to the nitrogen fertilization management, treatments with urea at $50 \mathrm{~kg} \mathrm{ha}^{-1}$ without inoculation and $100 \mathrm{~kg}$ ha $^{-1}$ with inoculation with $A$. brasilense provided a lower equilibrium price, presenting values in 2013/14 and 2014/15 of BRL 39.24 and BRL 39.57, respectively. On the other hand, when treatments with Super $\mathrm{N}$ at $150 \mathrm{~kg} \mathrm{ha}^{-1}$ dose and Super $\mathrm{N}$ at 0 $\mathrm{kg} \mathrm{ha}^{-1}$ dose, without and with inoculation with $A$. brasilense, respectively, were used in 2013/14 and
$2014 / 15$, the equilibrium price presented the highest values, at BRL 59.29 and BRL 72.51, respectively.

The magnitude of results inherent to profitability and economic return due to $\mathrm{N}$ doses is very high. This is not only due to different years of cultivation, but also as evident from other studies, a function of the locality studied, emphasizing, therefore, the importance of new studies of cost and profitability analysis, that consider nitrogen fertilization as a factor. Regarding inoculation, the use of $A$. brasilense, because of the variation in the obtained results, requires further studies related to the economic viability of this technology, along with the studies related to the improvement and adaptation of strains of Azospirillum, related to wheat genotypes, in order to obtain better results in crop productivity, combining yield and economic viability.

Brazil is an essential importing country of wheat, importing about $50 \%$ of what is consumed, becoming dependent on countries like Argentina, Canada and the United States, selling the cereal in dollars, in this way, buying wheat over BRL 50.00 per bag of $50 \mathrm{~kg}$, which is much higher than that paid to wheat produced in the country, which is around BRL 40.00 per bag. Thus, the need for the Government to provide incentive to the national wheat producers is evident, not only to stimulate production, but also to invest more in technology and in the reduction of the use of foreign currency for the acquisition of the product, since the value of the dollar is on the upward trend.

\section{Conclusions}

Increase in the doses of $\mathrm{N}$ applied, positively influences the grain yield of wheat.

Inoculation with Azospirillum brasilense alone does not increase grain yield. However, it may increase the efficiency of $\mathrm{N}$ fertilization, and it is feasible to use this diazotrophic bacterium even at high doses of $\mathrm{N}$.

The supply of $\mathrm{N}$ through urea, with inhibitor of 
the enzyme urease, was not economically superior to the use of conventional urea; therefore, it is recommended to use the conventional urea due to its ease of acquisition and lower cost.

The application of $140 \mathrm{~kg} \mathrm{ha}^{-1}$ of $\mathrm{N}$ together with the inoculation with Azospirillum brasilense in lowaltitude irrigated wheat fields that were cultivated after maize resulted in the highest grain yield.

The dose of $50 \mathrm{~kg} \mathrm{ha}^{-1}$ of $\mathrm{N}$ fertilization, in the absence of inoculation with Azospirillum brasilense with the conventional urea as source, provides greater economic viability in irrigated wheat cultivation. However, it is not sufficient to ensure high profitability with the production of wheat grains.

\section{References}

ABALOS, D.; JEFFERY, S.; SANZ-COBENA, A.; GUARDIA, G.; VALLEJO, A. Meta-analysis of the effect of urease and nitrification inhibitors on crop productivity and nitrogen use efficiency. Agriculture, Ecosystems \& Environment, Amsterdam, v. 189, n. 1, p. 136-144, 2014.

ACOSTA, J. A. de A.; AMADOR, T. J. C.; SILVA, L. S. da; SANTI, A.; WEBER, M. A. Decomposição da fitomassa de plantas de cobertura e liberação de nitrogênio em função da quantidade de resíduos aportada ao solo sob sistema plantio direto. Ciência Rural, Santa Maria, v. 44, n. 5, p. 801-809, 2014.

AGUIAR, R. A. D.; SILVEIRA, P. M. D.; MOREIRA, J. A. A.; WANDER, A. E. Análise econômica de diferentes práticas culturais na cultura do milho (Zea mays L.). Pesquisa Agropecuária Tropical, Goiânia, v. 38, n. 4, p. 241-248, 2008.

ALBRECHT, J. C.; SILVA, M. S. e; ANDRADE, J. M. V. de; SCHEEREN, P. L.; TRINDADE, M. G.; SOARES SOBRINHO, J.; SOUSA, C. N. A. de; BRAZ, A. J. B. P.; RIBEIRO JUNIOR, W. Q.; SOUSA, M. A. de; FRONZA, V.; YAMANAKA, C. H. Trigo BRS 264: cultivar precoce com alto rendimento de grãos indicada para o Cerrado do Brasil Central. Planaltina: EMBRAPA Cerrados, 2006. $18 \mathrm{p}$.

BARASSI, C. A.; SUELDO, R. J.; CREUS, C. M.; CARROZZI, L.; CASANOVAS, E. M.; PEREYRA, M. A. Potencialidad de Azospirillum en optimizer el crecimiento vegetal bajo condiciones adversas. In:
CASSÁN, F. D.; GARCIA DE SALAMONE, I. (Ed.). Azospirillum ssp.: cell physiology, plant interactions and agronomic research in Argentina. Argentina: Asociación Argentina de Microbiologia, 2008. p. 49-59.

BASHAN, Y.; BUSTILLOS, J. J.; LEYVA, L. A.; HERNANDEZ, J. P.; BACILIO, M. Increase in auxiliary photoprotective photosynthetic pigmentsin wheat seedlings induced by Azospirillum brasilense. Biology and Fertility of Soils, Berlin, v. 42, n. 4, p. 279-285, 2006.

BASHAN, Y.; HOLGUIN, G.; DE BASHAN, L. E. Azospirillum-plant relationships: physiological, molecular, agricultural, and environmental advances (1997-2003). Canadian Journal of Microbiology, Ottawa, v. 50, n. 8, p. 521-577, 2004.

CANTARELlA, H.; RAIJ, B. VAN; CAMARGO, C. E. O. Cereais. In: RAIJ, B. VAN; CANTARELLA, H.; QUAGGIO, J. A.; FURLANI, A. M. C. Recomendações de adubação e calagem para o Estado de São Paulo. Campinas, Brazil: Instituto Agronômico/Fundação IAC, Campinas, 1997, p. 70-72.

CANTARELLA, H.; TRIVELIN, P. C. O.; CONTIN, T. L. M.; DIAS, F. L. F.; ROSSETTO, R.; MARCELINO, R.; COIMBRA, R. B.; QUAGGIO, J. A. Ammonia volatilisation from urease inhibitor-treated urea applied to sugarcane trash blankets. Scientia Agricola, Piracicaba, v. 65, n. 4, p. 397-401, 2008.

CAZETTA, D. A.; FORNASIERI FILHO, D.; ARF, O. Resposta de cultivares de trigo e triticale ao nitrogênio no sistema de plantio direto. Cientifica, Jaboticabal, v. 35, n. 2, p. 155-165, 2007.

COMPANHIA NACIONAL DE ABASTECIMENTOCONAB. Avaliação da safra agrícola 2016/2017: Décimo segundo levantamento - setembro/2017. Brasília: CONAB, 2017. Disponível em: <http://www.conab.gov. br/OlalaCMS/uploads/arquivos/17_09_12_10_14_36_ boletim_graos_setembro_2017.pdf $>$ Acesso em: 30 set. 2017.

CUI, Z.; ZHANG. F.; CHEN, X.; DOU, Z.; LI, J. Inseason nitrogen management strategy for winter wheat: maximizing yields, minimizing environmental impact in an over-fertilization context. Field Crops Research, Amsterdam, v. 116, n.1-2, p. 140-146, 2010.

DUETE, R. R. C.; MURAOKA, T.; SILVA, E. C. da; TRIVELIN, P. C. O.; AMBROSANO, E. J. Viabilidade econômica de doses e parcelamentos da adubação nitrogenada na cultura do milho em Latossolo Vermelho Eutrófico. Acta Scientiarum. Agronomy, Maringá, v. 31, n. 1, p. 175-181, 2009. 
EMPRESA BRASILEIRA DE PESQUISA AGROPECUÁRIA - EMBRAPA. Centro Nacional de Pesquisa de Solos. Sistema brasileiro de classificação de solos. 3. ed. Brasília: Embrapa, 2013. 353 p.

FERREIRA, J. P.; ANDREOTTI, M.; ARF, O.; KANEKO, F. H.; NASCIMENTO, V.; SABUNDJIAN, M. T. Inoculação com Azospirillum brasilense e nitrogênio em cobertura no trigo em região de Cerrado. Tecnologia \& Ciência Agropecuária, João Pessoa, v. 8, n. 3, p. 27-32, 2014.

GALINDO, F. S.; LUDKIEWICZ, M. G. Z.; BELLOTE, J. L. M.; SANTINI, J. M. K.; TEIXEIRA FILHO, M. C. M.; BUZETTI, S. Épocas de inoculação com Azospirillum brasilense via foliar afetando a produtividade da cultura do trigo irrigado. Tecnologia \& Ciência Agropecuária, João Pessoa, v. 9, n. 2, p. 43-48, 2015.

GALINDO, F. S.; TEIXEIRA FILHO, M. C. M.; BUZETTI, S.; SANTINI, J. M. K.; BELLOTTE, J. L. M.; LUDKIEWICZ, M. G. Z.; ANDREOTTI, M.; SILVA, V. M.; GARCIA, C. M. P. Chemical soil attributes after wheat cropping under nitrogen fertilization and inoculation with Azospirillum brasilense. Semina: Ciências Agrárias, Londrina, v. 38, n. 2, p. 659-669, 2017.

GITTI, D. D. C.; ARF, O.; MELERO, M.; RODRIGUES, R. A. F.; TARSITANO, M. A. A. Influence of nitrogen fertilization and green manure on the economic feasibility of no-tilled wheat in the Cerrado. Revista Ceres, Viçosa, MG, v. 59, n. 2, p. 246-253, 2012.

GOMES, R. F.; SILVA, A. G.; ASSIS, R. L.; PIRES, F. R. Efeito de doses e da época de aplicação de nitrogênio nos caracteres agronômicos da cultura do milho sob plantio direto. Revista Brasileira de Ciência do Solo, Viçosa, MG, v. 31, n. 5, p. 931-938, 2007.

HUNGRIA, M. Inoculação com Azospirillum brasilense: inovação em rendimento a baixo custo. Londrina: EMBRAPA Soja, 2011. 37 p. (Embrapa Soja. Documentos, 325).

HUNGRIA, M.; CAMPO, R. J.; SOUZA, S. E. M.; PEDROSA, F. O. Inoculation with selected strains of Azospirillum brasilense and A. lipoferum improves yields of maize and wheat in Brazil. Plant and Soil, Amsterdam, v. 331, n. 1-2, p. 413-425, 2010.

KANEKO, F. H.;ARF, O.; GITTI, D. D. C.; TARSITANO, M. A. A.; RAPASSI, R. M. A.; VILELA, R. G. Custos e rentabilidade do milho em função do manejo do solo e da adubação nitrogenada. Pesquisa Agropecuária Tropical, Goiânia, v. 40, n. 1, p. 102-109, 2010.
KANEKO, F. H.; SABUNDJIAN, M. T.; ARF, O.; FERREIRA, J. P.; GITTI, D. D. C.; NASCIMENTO, V.; LEAL, A. J. F. Análise econômica do milho em função da inoculação com Azospirillum, fontes e doses de $\mathrm{N}$ em Cerrado de baixa altitude. Revista Brasileira de Milho e Sorgo, Sete Lagoas, v. 14, n. 1, p. 23-37, 2015.

LARA CABEZAS, W. A. R.; TRIVELIN, P. C. O.; KONDÖRFER, G. H.; PEREIRA, S. Balanço da adubação nitrogenada sólida e fluida de cobertura na cultura de milho, em sistema de plantio direto no triângulo mineiro (MG). Revista Brasileira de Ciência do Solo, Viçosa, MG, v. 24, n. 4, p. 363-376, 2000.

LEMOS, J. M.; GUIMARÃES, V. F.; VENDRUSCOLO, E. C. G.; SANTOS, M. F.; OFFEMANN, L. C. Resposta de cultivares de trigo à inoculação de sementes com Azospirillum brasilense, e à adubação nitrogenada em cobertura. Cientifica, Jaboticabal, v. 41, n. 2, p. 189-198, 2013.

MARTIN, N. B.; SERRA, R.; OLIVEIRA, M. D. M.; ÂNGELO, J. A.; OKAWA, H. Sistema integrado de custos agropecuários-CUSTAGRI. Informações Econômicas, São Paulo, v. 28, n. 1, p. 7-28, 1998.

MATSUNAGA, M.; BEMELMANS, P. F.; TOLEDO, P. N. E.; DULLEY, R. D.; OKAWA, H.; PEDROSO, I. A. Metodologia de custo de produção utilizada pelo IEA. Agricultura em São Paulo, São Paulo, v. 23, n. 1, p. 123139, 1976.

MEGDA, M. M.; BUZETTI, S.; ANDREOTTI, M.; TEIXEIRA FILHO, M. C. M.; VIEIRA, M. X. Resposta de cultivares de trigo ao nitrogênio em relação às fontes e épocas de aplicação sob plantio direto e irrigação por aspersão. Ciência e Agrotecnologia, Lavras, v. 33, n. 4, p. 1055-1060, 2009.

NUNES, P. H. M. P.; AQUINO, L. A.; SANTOS, L. P. D. dos; XAVIER, F. O.; DEZORDI, L. R.; ASSUNÇÃO, N. S. Produtividade do trigo irrigado submetido à aplicação de nitrogênio e à inoculação com Azospirillum brasilense. Revista Brasileira de Ciência do Solo, Viçosa, MG, v. 39, n. 1, p. 174-182, 2015.

POVH,F.P.; MOLIN, J.P.; GIMENEZ, L. M.; PAULETTI, V.; MOLIN, R.; SALVI, J. V. Comportamento do NDVI obtido por sensor ótico ativo em cereais. Pesquisa Agropecuária Brasileira, Brasília, v. 43, n. 8, p. 10751083, 2008.

PRANDO, A. M.; ZUCARELI, C.; FRONZA, V.; BASSOI, M. C.; OLIVEIRA, F. Á. Formas de ureia e doses de nitrogênio em cobertura no desempenho agronômico de genótipos de trigo. Semina: Ciências Agrárias, Londrina, v. 33, n. 2, p. 621-632, 2012. 
PRANDO, A. M.; ZUCARELI, C.; FRONZA, V.; OlIVEIRA, F. A.; OLIVEIRA JÚNIOR, A. Características produtivas do trigo em função de fontes e doses de nitrogênio. Pesquisa Agropecuária Tropical, Goiânia, v. 43, n. 1, p. 34-41, 2013.

RAIJ, B. Van; ANDRADE, J. C.; CANTARELLA, H.; QUAGGIO, J. A. Análise química para avaliação da fertilidade de solos tropicais. Campinas: IAC, Campinas, $2001.285 \mathrm{p}$.

SABUNDJIAN, M. T.; ARF, O.; KANEKO, F. H.; NASCIMENTO, V. Doses de nitrogênio no feijão de inverno em sucessão à gramíneas com e sem inoculação de Azospirillum brasilense: análise econômica. Revista Brasileira de Engenharia de Biossistemas, Tupã, v. 8, n. 2, p. 139-145, 2014.

SALA, V. M. R.; CARDOSO, E. J. B. N.; FREITAS, J. D.; SILVEIRA, A. D. Resposta de genótipos de trigo à inoculação de bactérias diazotróficas em condições de campo. Pesquisa Agropecuária Brasileira, Brasília, v. 42, n. 6, p. 833-842, 2007.

SILVA, E. C.; BUZETTI, S.; LAZARINI, E. Aspectos econômicos da adubação nitrogenada na cultura do milho em sistema plantio direto em Latossolo Vermelho distroférrico fase Cerrado. Revista Brasileira de Milho e Sorgo, Sete Lagoas, v. 4, n. 3, p. 286-297, 2005.

SILVA, E. C.; MURAOKA, T.; MONTEIRO, R. O. C.; BUZETTI, S. Análise econômica da adubação nitrogenada no milho sob plantio direto em sucessão a plantas de cobertura em Latossolo Vermelho. Acta Scientiarum. Agronomy, Maringá, v. 29, n. 4, p. 445-452, 2007.

TEIXEIRA FILHO, M. C. M.; BUZETTI, S.; ALVAREZ, R. C. F.; FREITAS, J. G.; ARF, O.; SÁ, M. E. Desempenho agronômico de cultivares de trigo em resposta a população de plantas e a adubação nitrogenada. Cientifica, Jaboticabal, v. 36, n. 2, p. 97-106, 2008.
TEIXEIRA FILHO, M. C. M.; BUZETTI, S.; ALVAREZ, R. C. F.; FREITAS, J. G.; ARF, O.; SÁ, M. E. Resposta de cultivares de trigo irrigado por aspersão ao nitrogênio em cobertura na região do Cerrado. Acta Scientiarum. Agronomy, Maringá, v. 29, n. 3, p. 421-425, 2007.

TEIXEIRA FILHO, M. C. M.; BUZETTI, S.; ANDREOTTI, M.; ARF, O.; BENETT, C. G. S. Doses, fontes e épocas de aplicação de nitrogênio em trigo irrigado em plantio direto. Pesquisa Agropecuária Brasileira, Brasília, v. 45, n. 8, p. 797-804, 2010a.

TEIXEIRA FILHO, M. C. M.; BUZETTI, S.; ANDREOTTI, M.; BENETT, C. G. S.; ARF, O.; SÁ, M. E. Wheat nitrogen fertilization under no till on the low altitude brazilian Cerrado. Journal of Plant Nutrition, New York, v. 37, n. 11, p. 1732-1748, 2014.

TEIXEIRA FILHO, M. C. M.; TARSITANO, M. A. A.; BUZETTI, S.; BERTOLIN, D. C.; SOUZA COLOMBO, A. de; NASCIMENTO, V. Análise econômica da adubação nitrogenada em trigo irrigado sob plantio direto no Cerrado. Revista Ceres, Viçosa, MG, v. 57, n. 4, p. 446-453, 2010b.

THEAGO, E. Q.; BUZETTI, S.; TEIXEIRA FILHO, M. C. M.; ANDREOTTI, M.; MEGDA, M. M.; BENETT, C. G. S. Doses, fontes e épocas de aplicação de nitrogênio influenciando teores de clorofila e produtividade do trigo. Revista Brasileira de Ciência do Solo, Viçosa, MG, v. 38, n. 6, p. 1826-1835, 2014.

TIEN, T. M.; GASKINS, M. H.; HUBBELL, D. H. Plant growth substances produced by Azospirillum brasilense and their effect on the growth of pearl millet (Pennisetum americanum L.). Applied and Environmental Microbiology, Washington, v. 37, n. 5, p. 1016-1024, 1979. 